\title{
Analyzing the Effect of Water Body on the Thermal Environment and Comfort at Indoor and Outdoor Spaces in Tropical University Campus
}

\author{
Farhadur Reza, Shoichi Kojima, and Wataru Ando
}

\begin{abstract}
Water bodies play a significant role in its surrounding thermal environment. Thermal comfort in university spaces is critical that affects the students' health and performance as well as the staffs. This study investigated thermal environment and comfort near lakeside and non-lakeside tropical university spaces. Standard Effective Temperature (SET*) have been calculated using recorded air temperature, relative humidity, globe temperature, air velocity, clothing insulation and metabolic rate to evaluate the thermal comfort in outdoor and indoor spaces. The effects of weather parameters have been clearly visible on the comfort index. The calculated SET* values indicate that the outdoor thermal comfort near a lake is much closer to the standard comfort zone than non-lakeside outdoor space. In the case of indoor thermal comfort, however, slightly a different scenario has been observed. To achieve the desirable indoor thermal environment, some design considerations are recommended based on findings.
\end{abstract}

Index Terms-Thermal environment, thermal comfort, standard effective temperature (SET*), water body.

\section{INTRODUCTION}

Over the last century, the world is becoming predominantly urban [1]. Increasing urbanization rates are associated with land use and land cover changes, air pollution, and a higher demand for energy consumption [2]. Considering the rapid growth of urban population, the global built-up area is also expected to be increased proportionately [3]. The low reflectivity of the urban surface combined with a high density of construction results in an accumulation of heat in the urban environment. This causes a higher temperature that consequently increases discomfort [4]. Consequently, numerous studies have been conducted to attenuate discomfort in urban spaces.

Triyuly, Triyadi, and Wonorahardjo [5] claimed that air temperature could be reduced during the daytime by exploiting the water body's properties of air-cooling effect and delay in re-emission of heat energy. Wu, Wang, Fan, and Xia [6] showed that reservoir, lake, and green space have direct impacts on the urban thermal environment. Employing its transparency, high thermal capacity, and evaporation process the water bodies act as an efficient heat sink and

Manuscript received March 10, 2021; revised May 29, 2021. This work was funded by the Government of Japan under MEXT PhD Scholarship, 2018.

The author are with the Department of Civil Engineering and Architecture, Saga University, Japan, on leave from the Jahangirnagar University, Dhaka, Bangladesh (e-mail: farhadrezaurp@juniv.edu, shokjm@cc.saga-u.ac.jp, 20710001@edu.cc.saga-u.jp). reduce the air temperature [7]. These unique characteristics of water bodies attract city planners and architects around the globe to incorporate water bodies in their designs to regulate urban thermal environments [8]. Jusuf, Wong, and Syafii [9] carried out a study in Singapore and found air temperatures cooler up to $1.8^{\circ} \mathrm{C}$ near the water features compared to surrounding built areas during clear sunny days. Guo-yu et al. [10] stated that water bodies in urban areas significantly affect the urban climate and mitigate the Urban Heat Island (U.H.I.) effect due to the thermal properties of water and evaporation. They identified a water body with a surface area of $16 \mathrm{~m}^{2}$ that could cool by $1^{\circ} \mathrm{C}$ up to $2826 \mathrm{~m}^{3}$ of surrounding space. Syafii et al. [11] found that the thermal environment inside an urban canyon with a pond is better than that without a pond, particularly during the daytime. Jin, Shao, and Zhang [12] mentioned that being one of the constituent elements of the underlying surface, the water body plays a regulating effect on the microclimate of residential districts, especially in summer. Their results suggest that both centralized and scattered water bodies can improve the microclimate of the residential district. Mohammad S. Albdour and Balint Baranyai [13] conducted a study to measure the effect of water features on the microclimate in Pecs, Hungary. Their results showed that water elements played a role in reducing air temperature and mean radiant temperature, while a slight effect on Predicted Mean Vote (PMV). Farajzadeh and Matzarakis [14] conducted a study on the thermal comfort conditions around a lake in Iran. Analyzing Cooling Power and Physiologically Equivalent Temperature (PET), they identified the suitable periods for tourism and recreation activities. Xi, Li, Mochida and Meng [15] investigated outdoor thermal environment and comfort around campus clusters in Guangzhou, China. They identified that different outdoor thermal environments resulted from different man-made elements such as pilotis, squares, lawns, and lakes.

However, most of these studies, primarily focused on the role of water bodies on the outdoor thermal environment and comfort. The significance of the indoor thermal environment and comfort cannot be undermined, especially in educational infrastructures [16]. The unsatisfactory thermal environment in the classroom can result in undesirable conditions for both teachers and students and can adversely affect their performance and productivity [17]. In the case of educational infrastructure, the thermal environment in indoor and outdoor spaces is critical. In this context, this study attempts to analyze the effect of the water body on thermal comfort in indoor and outdoor university spaces. To assess thermal comfort, Standard Effective Temperature (SET*) have been calculated using air temperature, relative humidity, globe 
temperature, and air velocity recorded during field measurement in typical summer days along with clothing insulation and metabolic rate.

\section{StUdy AREA PROFILE}

This study was conducted in two classrooms and those surrounding spaces of the Faculty of Arts and Humanities Building and the Faculty of Social Sciences Building, Jahangirnagar University, Bangladesh. Geographically it lies between $23^{\circ} 52^{\prime} \mathrm{N}$ and $90^{\circ} 16^{\prime} \mathrm{E}$. The university comprises an area of about $2.8 \mathrm{~km}^{2}$ and is located $32 \mathrm{~km}$ north of Dhaka city. Here climate can be characterized as hot, rainy, humid summers and dry and cool winter possessing total annual rainfall of about $1,800 \mathrm{~mm}$ and $86 \%$ mean relative humidity. More temperate months range from April to October [18]-[20]. Table I presents an overview of the selected classrooms.

$\mathrm{M}=$ Position of Measurement Devices
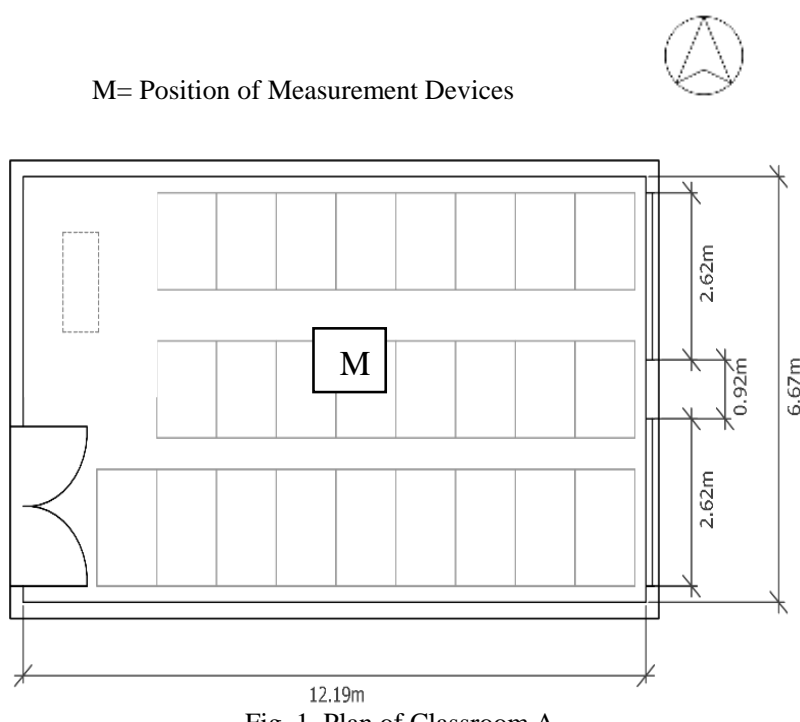

Fig. 1. Plan of Classroom A.

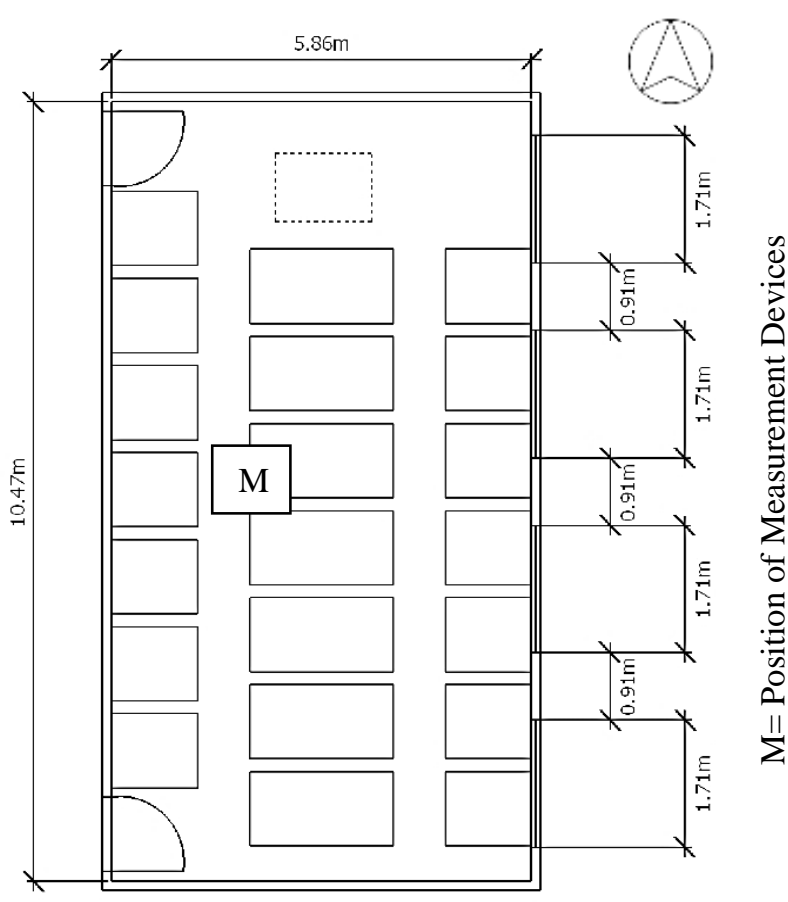

Fig. 2. Plan of Classroom B.
Classroom A (Fig. 1) is located on the second floor of a three-storied academic building near a lake of 1.5 hectares. In contrast, Classroom B (Fig. 2) is located on the second floor of a four-storied non-lakeside academic building. The window to wall ratio (WWR) of Classroom A and B are 7.6\% and $15.3 \%$, respectively.

TABLE I: MAJOR SPECIFICATIONS OF CLASSROOMS

\begin{tabular}{lll}
\hline \hline Parameter & Classroom A & Classroom B \\
\hline Dimensions & $12.19 \mathrm{~m}^{*} 6.67 \mathrm{~m} * 3.5 \mathrm{~m}$ & $10.47 \mathrm{~m}^{*} 5.86 \mathrm{~m} * 3.2 \mathrm{~m}$ \\
Area & $81.3 \mathrm{~m}^{2}$ & $61.4 \mathrm{~m}^{2}$ \\
Volume & $284.6 \mathrm{~m}^{3}$ & $196.5 \mathrm{~m}^{3}$ \\
Level & 2nd floor & 2nd floor \\
$\begin{array}{l}\text { Orientation } \\
\text { of Window }\end{array}$ & East & East \\
$\begin{array}{l}\text { Window } \\
\text { dimensions }\end{array}$ & $0.38 \mathrm{~m} * 1.27 \mathrm{~m}$ & $1.7 \mathrm{~m} * 1.95 \mathrm{~m}$ \\
Window area & $9.1 \mathrm{~m}^{2}$ & $13.3 \mathrm{~m}^{2}$ \\
\hline \hline
\end{tabular}

\section{Methodology}

Device setup, objective measurement, SET* calculation have been conducted based on the procedures prescribed by ASHRAE Standard 55-2017.

\section{A. Device Setup}

All the devices (Table II, Fig. 3, ) were placed in the center of the classroom (Fig. 4, and Fig. 5) at $1.1 \mathrm{~m}$ above the floor. Additionally, one set of similar devices was also placed outside the building to investigate outdoor microclimatic data.

\section{B. Measurement}

Field measurement was carried out during typical summer days from May 21 to May 23, 2019. Six hours of data, from 9:00 to 15:00 Local Standard Time (L.S.T.), were continuously recorded with a 1-minute time interval. All the windows and doors of the classrooms were open during measurement.

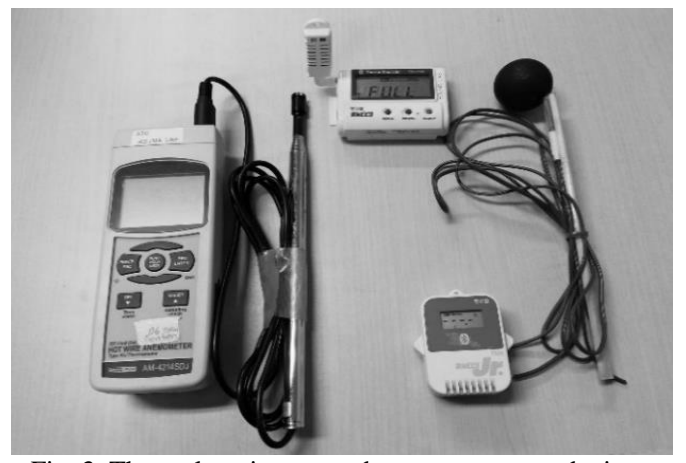

Fig. 3. Thermal environment data measurement devices.

\section{Calculation}

At first, Mean Radiant Temperature (MRT) was calculated by a self-made program on Engineering Equation Solver (E.E.S.). Then, MRT values along with air temperature, air velocity, relative humidity, metabolic rate, and clothing level were put in CBE Thermal Comfort Tool to determine SET*. Students are usually involved in reading and writing in seated conditions within the classrooms with a metabolic rate of 1 Met. Simultaneously, 0.5 clo value for a typical summer clothing ensemble was used in the calculation [21]. 
TABLE II: WEATHER DATA MEASUREMENT DEVICES

\begin{tabular}{|c|c|c|c|c|}
\hline Parameter & Instruments & $\begin{array}{l}\text { Time } \\
\text { Interval }\end{array}$ & Range & Accuracy \\
\hline $\begin{array}{l}\text { Air } \\
\text { temperature }\end{array}$ & $\begin{array}{l}\text { Thermo Recorder } \\
\text { TR-72wb }\end{array}$ & $1 \mathrm{~min}$. & $\begin{array}{l}0 \text { to } \\
55^{\circ} \mathrm{C}\end{array}$ & $\pm 0.5^{\circ} \mathrm{C}$ \\
\hline $\begin{array}{l}\text { Relative } \\
\text { humidity }\end{array}$ & $\begin{array}{l}\text { Thermo Recorder } \\
\text { TR-72wb }\end{array}$ & $1 \mathrm{~min}$. & $\begin{array}{l}10 \text { to } \\
95 \% \mathrm{RH}\end{array}$ & $\pm 5 \% \mathrm{RH}$ \\
\hline $\begin{array}{l}\text { Globe } \\
\text { temperature }\end{array}$ & $\begin{array}{l}\text { Thermo Recorder } \\
\text { TR- } 45\end{array}$ & $1 \mathrm{~min}$. & $\begin{array}{l}-199 \text { to } \\
1760^{\circ} \mathrm{C}\end{array}$ & $\begin{array}{l} \pm\left(0.5^{\circ} \mathrm{C}+\right. \\
0.3 \% \text { of } \\
\text { reading })\end{array}$ \\
\hline Air velocity & $\begin{array}{l}\text { Anemometer } \\
\text { AM4214SDJ }\end{array}$ & $1 \mathrm{~min}$. & $\begin{array}{l}0.2 \text { to } \\
5.0 \mathrm{~m} / \mathrm{s}\end{array}$ & $\begin{array}{l} \pm(5 \%+a) \\
\text { reading }\end{array}$ \\
\hline
\end{tabular}

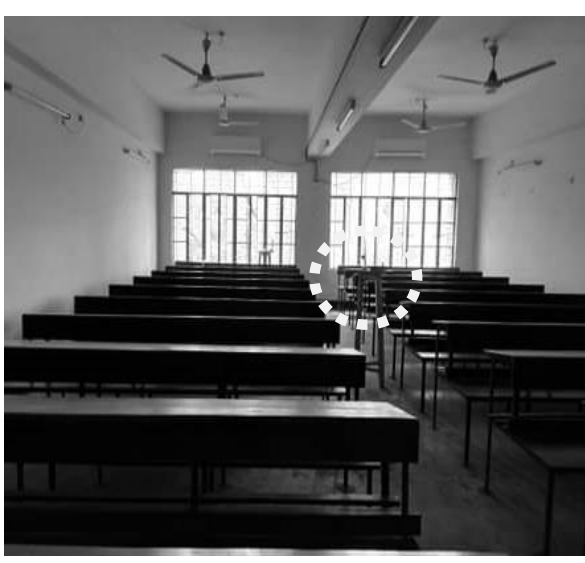

Fig. 4. Device set up in Classroom A.

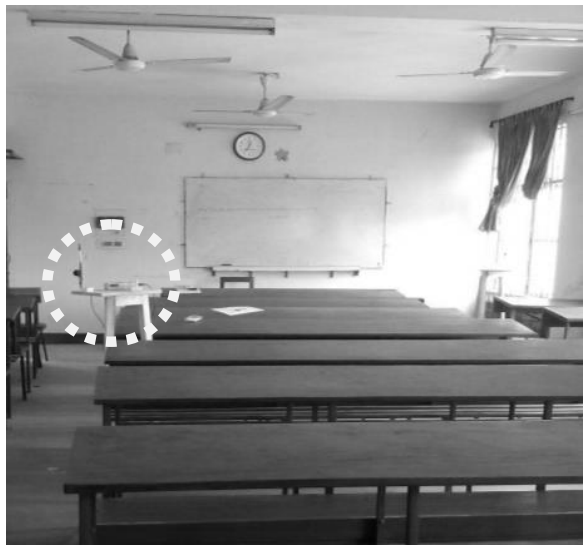

Fig. 5. Device set up in Classroom B.

\section{RESUlTS AND DisCUSSION}

\section{A. Indoor and Outdoor Environmental Parameters}

Fig. 6 and Fig. 7 present the indoor and outdoor air temperature $\left(\mathrm{Ta}_{\mathrm{i}}\right.$ and $\left.\mathrm{Ta}_{\mathrm{o}}\right)$, and relative humidity $\left(\mathrm{RH}_{\mathrm{i}}\right.$ and $\mathrm{RH}_{\mathrm{o}}$ ) respectively in different measurement dates. The outdoor weather parameters e.g., air temperature, relative humidity, and air velocity, fluctuated more than those indoor counterparts.

\section{B. Environmental Parameters for Classroom A}

The solar radiation found lower in the morning and started to increase as the time pressing on. Thus, the air temperature inside the classroom $\left(\mathrm{Ta}_{\mathrm{i}}\right)$ was found lower in the morning, especially up to 10:11 Local Standard Time (L.S.T.) on May 22, and up to 10:27 LST on May 23. The Ta $\mathrm{a}_{\mathrm{i}}$ usually started to increase steadily with the progress of time in response to solar radiation in all measurement dates. The overall $\mathrm{Ta}_{\mathrm{i}}$ was found higher (average $\mathrm{Ta}_{\mathrm{i}} 33.3^{\circ} \mathrm{C}$ ) on May 21 when the maximum $\mathrm{Ta}_{\mathrm{i}}$ was measured as $34.6^{\circ} \mathrm{C}$. On May 23, the average $\mathrm{Ta}_{\mathrm{i}}$ was lower $\left(30.5^{\circ} \mathrm{C}\right)$ than other measurement dates, with a minimum $\mathrm{Ta}_{\mathrm{i}}$ value of $28.9^{\circ} \mathrm{C}$. For Classroom $\mathrm{A}$, the $\mathrm{Ta}_{\mathrm{o}}$ was lower than $\mathrm{Ta}_{\mathrm{i}}$ up to 11:00 L.S.T. on May 22 and 23. On average, the $\mathrm{Ta}_{\mathrm{o}}$ was $1.8^{\circ} \mathrm{C}$ lower than $\mathrm{Ta}_{\mathrm{i}}$ up to $11: 00$ L.S.T. on May 22, and $0.6^{\circ} \mathrm{C}$ on May 23. The outdoor weather was overcast up to 11:00 L.S.T. on May 22. The lowest $\mathrm{Ta}_{\mathrm{o}}$ was measured as $26.5^{\circ} \mathrm{C}$ on May 22 , followed by $27.6^{\circ} \mathrm{C}$ on May 23. Apart from this, the $\mathrm{Ta}_{\mathrm{o}}$ was higher than $\mathrm{Ta}_{\mathrm{i}}$. The $\mathrm{Ta}_{\mathrm{o}}$ was 0.9 and $0.8^{\circ} \mathrm{C}$ higher than $\mathrm{Ta}_{\mathrm{i}}$ on May 21 and 22 , respectively. The highest $\mathrm{Ta}_{\mathrm{o}}$ was $37.8^{\circ} \mathrm{C}$ on May 22 and $36.8^{\circ} \mathrm{C}$ on May 21 during the afternoon period.

The indoor relative humidity $\left(\mathrm{RH}_{\mathrm{i}}\right)$ of Classroom A formed comparatively stable trend lines on May 21 and 23 (Fig. 7. (a) \& (c)). The highest $\mathrm{RH}_{\mathrm{i}}$ was found as $74 \%$, with the corresponding Tai of $29^{\circ} \mathrm{C}$ on May 23. While on May 21, $73 \% \mathrm{RH}_{\mathrm{i}}$ was recorded with the corresponding $\mathrm{Ta}_{\mathrm{i}}$ of $31.8^{\circ} \mathrm{C}$. The lowest $\mathrm{RH}_{\mathrm{i}}$ was found as $61 \%$ during the afternoon session on May 22. Following the $\mathrm{Ta}_{\mathrm{i}}$ trend in reverse order, the $\mathrm{RH}_{\mathrm{i}}$ was started to rise around 9:21 to 9:35 L.S.T., remained stable up to 10:00 L.S.T., and then dropped steadily up to 14:00 L.S.T. The $\mathrm{Ta}_{\mathrm{i}}$ started to fall between 9:21 and 9:35 L.S.T., approaches evenly up to 10:00 L.S.T., and increased steadily. Both the $\mathrm{Ta}_{\mathrm{i}}$ and $\mathrm{RH}_{\mathrm{i}}$ formed a more consistent trend on May 23 compared to other measurement dates. In response to higher outdoor air temperature, the outdoor relative humidity $\left(\mathrm{RH}_{\mathrm{o}}\right)$ was found lower than $\mathrm{RH}_{\mathrm{i}}$ entire of the measurement period on May 21. Higher $\mathrm{RH}_{\mathrm{o}}$ values were observed up to 11:00 L.S.T. on May 22, when the highest $\mathrm{RH}_{\mathrm{o}}$ was recorded as $84 \%$. The $\mathrm{RH}_{\mathrm{o}}$ started to drop sharply after 11:00 L.S.T. when the lowest value of $\mathrm{RH}_{0}$ was found as $47 \%$. A climbing trend of the Tao was observed at the same time. On May 23, the $\mathrm{RH}_{\mathrm{o}}$ was higher than $\mathrm{RH}_{\mathrm{i}}$ up to 10:00 L.S.T., remain similar until 11:27 L.S.T., and then dropped.

The air velocity inside Classroom A was higher on May 22, followed by May 23 (Table III). The maximum air velocity was measured as $1.24 \mathrm{~ms}^{-1}$ with an average value of $0.04 \mathrm{~ms}^{-1}$ on May 22. Ceiling fans were in operation from 12:07 to 12:23 L.S.T. on May 23 when the highest air velocity was recorded as $0.68 \mathrm{~ms}^{-1}$. Apart from this, ceiling fans were switched off in all the measurement periods. The doors and windows were open. Compared to other measurement dates, the air velocity outside Classroom $\mathrm{C}$ was marginally higher on May 22. The maximum air velocity was found as $3.23 \mathrm{~ms}^{-1}$ with an average of $0.73 \mathrm{~ms}^{-1}$ on that date. A similar average outdoor air velocity was determined on May 21 and 23 . However, the maximum outdoor air velocity was measured as $1.92 \mathrm{~ms}^{-1}$ on May 21 and $2.92 \mathrm{~ms}^{-1}$ on May 23.

TABLE III: INDOOR AND OUTDOOR AIR VELOCITY

\begin{tabular}{lllll}
\hline \hline \multirow{2}{*}{ Date } & \multicolumn{2}{l}{$\begin{array}{l}\text { Average Indoor Air Velocity } \\
\left(\mathrm{ms}^{-1}\right)\end{array}$} & $\begin{array}{l}\text { Average Outdoor Air } \\
\text { Velocity }\left(\mathrm{ms}^{-1}\right)\end{array}$ \\
\cline { 2 - 5 } & Classroom A & $\begin{array}{l}\text { Classroom } \\
\text { B }\end{array}$ & $\begin{array}{l}\text { Classroom } \\
\text { A }\end{array}$ & $\begin{array}{l}\text { Classroom } \\
\text { B }\end{array}$ \\
\hline $21-05-2019$ & 0.006 & 0.02 & 0.5 & 0.7 \\
$22-05-2019$ & 0.04 & 0.18 & 0.7 & 0.7 \\
$23-05-2019$ & 0.02 & 0.06 & 0.5 & 0.6 \\
\hline
\end{tabular}

\section{Environmental Parameters for Classroom B}


Higher $\mathrm{Ta}_{\mathrm{i}}$ was observed in Classroom B on May 21. The maximum $\mathrm{Ta}_{\mathrm{i}}$ was measured as $33.3^{\circ} \mathrm{C}$ with an average of $32.8^{\circ} \mathrm{C}$. The $\mathrm{Ta}_{\mathrm{i}}$ remains lower up to 11:00 L.S.T. on May 22 when the minimum $\mathrm{Ta}_{\mathrm{i}}$ was recorded as $27.6^{\circ} \mathrm{C}$. Compared to other dates, the $\mathrm{Ta}_{\mathrm{i}}$ trend was found more stable throughout the entire measurement period on May 23. The $\mathrm{Ta}_{\mathrm{o}}$ was higher on May $21\left(\right.$ mean $\mathrm{Ta}_{\mathrm{o}} 37.7^{\circ} \mathrm{C}$ ) and May $22\left(\right.$ mean $\mathrm{Ta}_{\mathrm{o}}$ $35.5^{\circ} \mathrm{C}$ ). The highest $\mathrm{Ta}_{\mathrm{o}}$ was measured as $41.7^{\circ} \mathrm{C}$ on May 22 and $40.5^{\circ} \mathrm{C}$ on May 21 .
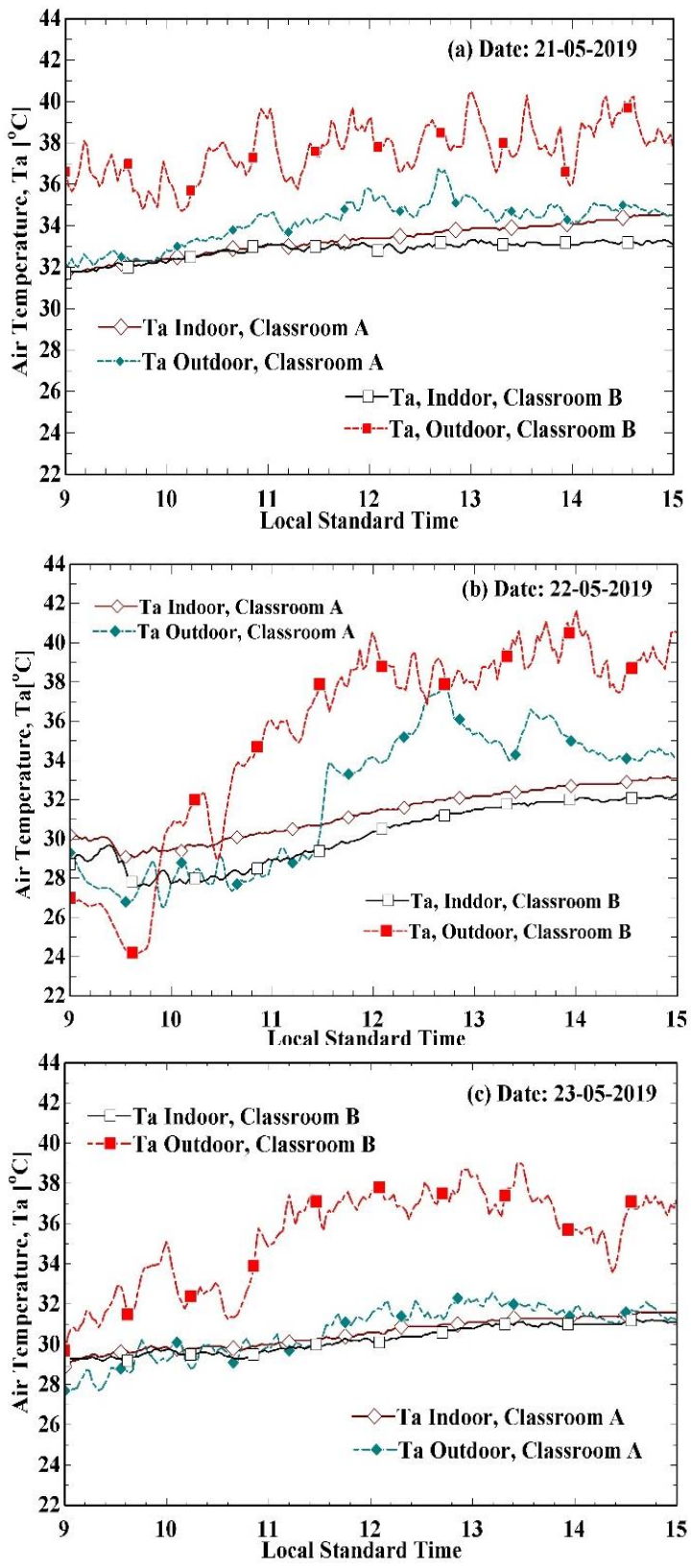

Fig. 6. Diurnal distribution of air temperature.

There was no lake near Classroom B. Hence, the absence of lake's cooling effects resulted higher $\mathrm{Ta}_{\mathrm{o}}$. The lowest $\mathrm{Ta}_{\mathrm{o}}$ was found at $24.2^{\circ} \mathrm{C}$ during the morning session on May 22 because of cloudy weather.

Both $\mathrm{RH}_{\mathrm{i}}$ and $\mathrm{RH}_{\mathrm{o}}$ were found higher on May 22, followed by May 21. The maximum and the minimum $\mathrm{RH}_{\mathrm{i}}$ and $\mathrm{RH}_{\mathrm{o}}$ were measured on May 22. The $\mathrm{RH}_{\mathrm{i}}$ was higher up to 10:40 L.S.T. when the maximum $\mathrm{RH}_{\mathrm{i}}$ was found as $78 \%$ on that date. Between 9:29 and 9:48 L.S.T., the $\mathrm{RH}_{\mathrm{o}}$ was found higher with a maximum value of $95 \%$. However, the $\mathrm{RH}_{\mathrm{i}}$ and
$\mathrm{RH}_{\mathrm{o}}$ started to fall as the $\mathrm{Ta}_{\mathrm{i}}$ and $\mathrm{Ta}_{\mathrm{o}}$ commenced to increase with the progress of time. The minimum $\mathrm{RH}_{\mathrm{i}}$ and $\mathrm{RH}_{\mathrm{o}}$ were recorded as $61 \%$ and $40 \%$, respectively. Identical to the $\mathrm{Ta}_{\mathrm{i}}$, the $\mathrm{RH}_{\mathrm{i}}$ approached more steadily on May 21 compared to other dates.
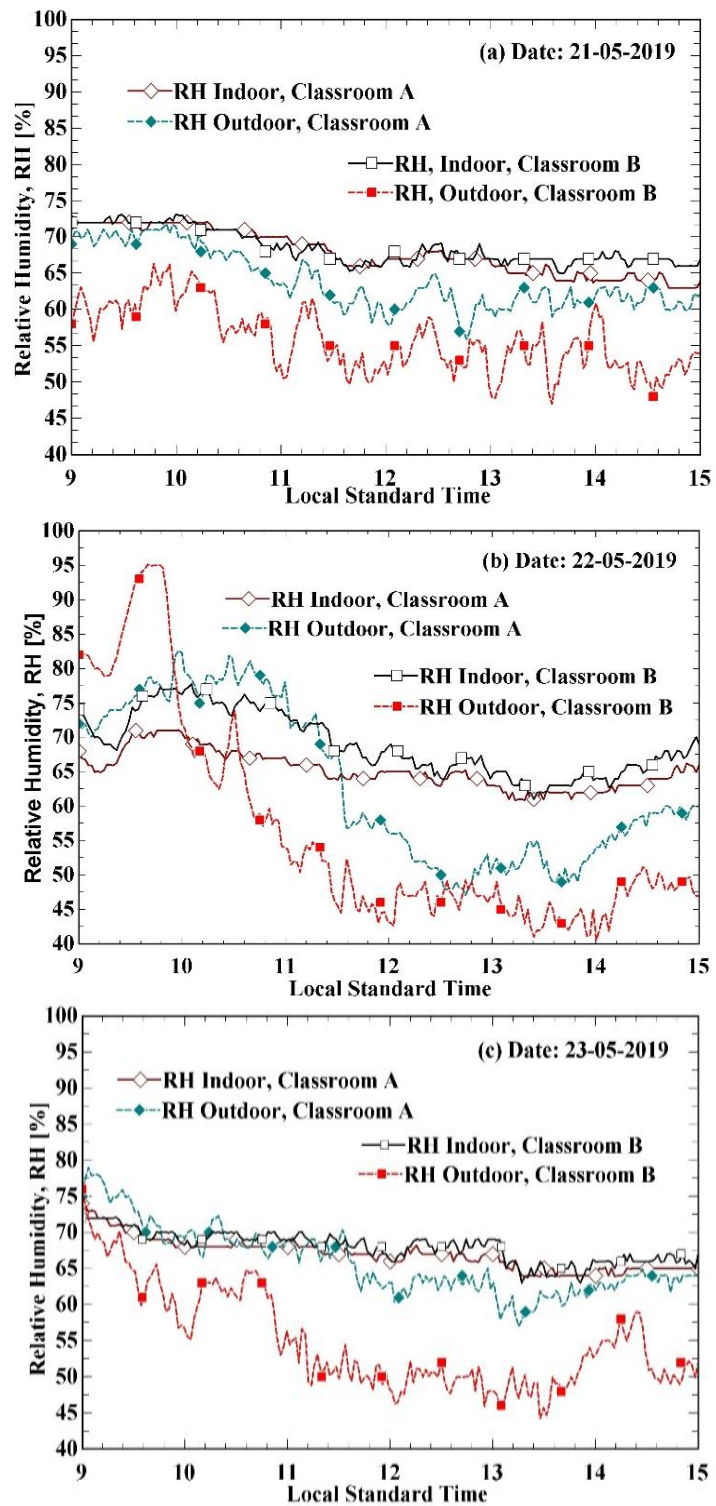

Fig. 7. Diurnal distribution of relative humidity.

Like Classroom A, the indoor air velocity was higher on May 22 in Classroom B (Table III). The highest air velocity was recorded as $1.34 \mathrm{~ms}^{-1}$ with an average of $0.18 \mathrm{~ms}^{-1}$ on that date. Ceiling fans were switched off in the Classroom B during the measurement dates except from 12:44 to 12:55 L.S.T. on May 23. The maximum air velocity was measured as $0.58 \mathrm{~ms}^{-1}$ with an average of $0.06 \mathrm{~ms}^{-1}$. The average indoor air velocity found comparatively lower $\left(0.02 \mathrm{~ms}^{-1}\right)$ on May 21. Air velocity in Classroom B was higher than Classroom A. larger window size of Classroom B allowed better air circulation. The mentionable air velocity was measured in the outdoor space of Classroom B. The average outdoor air velocity of three consecutive measurement dates were determined as $0.7,0.7$, and $0.6 \mathrm{~ms}^{-1}$, respectively. The highest outdoor air velocity was $3.97 \mathrm{~ms}^{-1}$ on May 21 and $3.7 \mathrm{~ms}^{-1}$ on May 23. 


\section{Indoor Thermal Comfort}

Calculated values of the indoor Standard Effective Temperature (SET*) in different measurement dates are plotted in Fig. 8. The SET* values inside the classrooms were found more stable than its outdoor counterparts in response to the frequent change of outdoor environmental parameters. The calculated outdoor SET* values for Classroom B were much higher than that of indoor in most of the measurement periods. However, in the case of Classroom A, the scenario was a little different.

The SET* values were low inside Classroom A and B in the morning and then, in response to the increase in air temperature, started to increase steadily. Similar air temperature up to10:30 and 10:00 L.S.T. on May 21 and 23, respectively, resulted in an almost similar trend of SET* values. The $\mathrm{SET}^{*}$ values were evident slightly higher in Classroom A than the Classroom B, especially on May 22. The maximum average difference between the indoor SET* values of Classroom A and $\mathrm{B}$ was $0.6^{\circ} \mathrm{C}$ during that date. These differences were determined as $0.4^{\circ} \mathrm{C}$ and $0.3^{\circ} \mathrm{C}$ on May 21 and 23, respectively. The indoor SET* values of Classroom B fluctuate more than Classroom A because of frequent air velocity.

On May 22, the indoor SET* values were closer to the ASHRAE-17 recommended comfort zone up to 10:30 L.S.T. During this period, the minimum SET* values were calculated as $23.3^{\circ} \mathrm{C}$ in Classroom $\mathrm{A}$ and $24.3^{\circ} \mathrm{C}$ in Classroom $\mathrm{B}$ with a sensation of 'Comfortable and Acceptable'. Lower air temperature coupled with notable air velocity yielded such comfort zone in SET* index. The SET* values were also found closer to the ASHRAE-17 recommended comfort zone on May 23 between 12:07 to 12:21 L.S.T. in Classroom A and 12:44 to 12:55 L.S.T. in Classroom B. During these periods, ceiling fans were in operation and the lowest $\mathrm{SET}^{*}$ values were calculated as $27.3^{\circ} \mathrm{C}$ in Classroom $\mathrm{A}$ and $28.8^{\circ} \mathrm{C}$ in Classroom B with a 'Slightly Warm' sensation.

Higher indoor SET* values were found in both classrooms due to higher air temperature on May 21. The highest SET* value was estimated as $36^{\circ} \mathrm{C}$ ('Hot' Sensation) with an average of $35.1^{\circ} \mathrm{C}$ in Classroom $\mathrm{A}$ and $35.3^{\circ} \mathrm{C}$ ('Hot' Sensation) with an average of $34.7^{\circ} \mathrm{C}$ in Classroom B on that date. The lower average air temperature dropped the average indoor SET* down on May 22 and 23. The average SET* values were $31.2^{\circ} \mathrm{C}$ and $31.1^{\circ} \mathrm{C}$ in Classroom $\mathrm{A}$, while $30.1^{\circ} \mathrm{C}$ and $30.8^{\circ} \mathrm{C}$ in Classroom $\mathrm{B}$ on those dates, respectively. Apart from May 21, the highest SET* values were calculated as $34.7^{\circ} \mathrm{C}$ in Classroom A and $34.3^{\circ} \mathrm{C}$ in Classroom B on May 22.

\section{E. Outdoor Thermal Comfort}

Fig. 9 depicts the outdoor SET* values of the classrooms in different measurement dates. Other than May 22, the SET* values outside Classroom A were found lower than Classroom B. The outdoor average SET* values of Classroom A and B were $26^{\circ} \mathrm{C}$ and $23.8^{\circ} \mathrm{C}$, respectively, up to 10:00 L.S.T. on that day. The lower air temperature $\left(26.3^{\circ} \mathrm{C}\right)$ and mentionable air velocity $\left(0.9 \mathrm{~ms}^{-1}\right)$ outside of the Classroom B resulted such lower SET* during that time. The lowest SET* values were calculated as $18.7^{\circ} \mathrm{C}$ and $22.2^{\circ} \mathrm{C}$ with 'Slightly Cool' sensation outside of Classroom $\mathrm{A}$ and $\mathrm{B}$ respectively on that period. The maximum outdoor SET* of Classroom B was calculated as $42.7^{\circ} \mathrm{C}$ with 'Very Hot' sensation on May 21 and $40.7^{\circ} \mathrm{C}$ with 'Very Hot' sensation on May 22. In Classroom A, the maximum outdoor SET* were found as $38.1^{\circ} \mathrm{C}$ with a 'Very Hot' sensation on May 21, followed by $36.9^{\circ} \mathrm{C}$ with 'Hot' sensation on May 22.
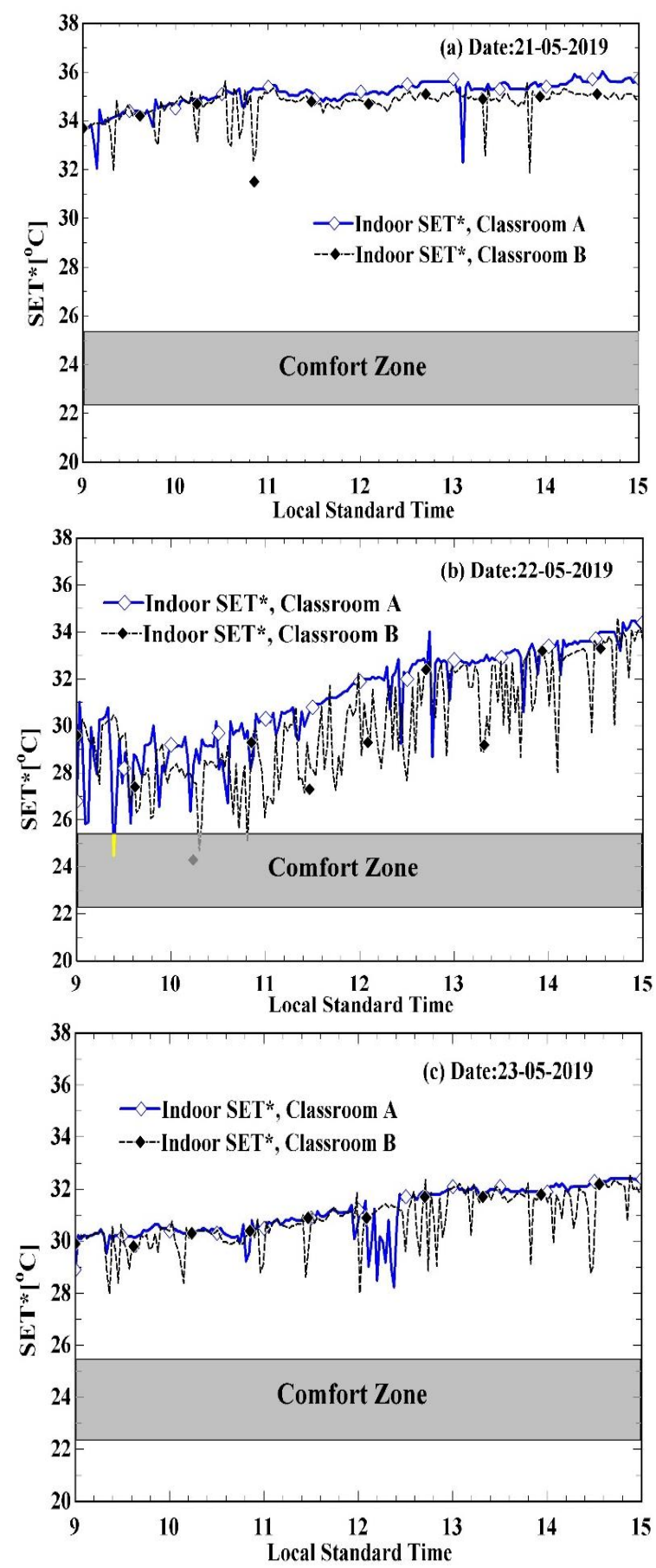

Fig. 8. Indoor SET* trend in different dates.

The average $\mathrm{SET}^{*}$ values outside of Classroom A were calculated as $34.3^{\circ} \mathrm{C}$ ('Warm' sensation), $29.4^{\circ} \mathrm{C}$ ('Slightly Warm' sensation), and $29.9^{\circ} \mathrm{C}$ ('Slightly Warm' sensation) on May 21, 22, and 23, respectively. While for Classroom B, the average outdoor SET* values were found as $37.6^{\circ} \mathrm{C}$ ('Very Hot' sensation), $33.3^{\circ} \mathrm{C}$ ('Warm' sensation), and $33.6^{\circ} \mathrm{C}$ ('Warm' sensation) on the same dates. The 'Comfortable and Acceptable' SET* values were determined 
outside of Classroom A between 9:27 and 9:43 LST, 9:57 and 9:59 LST, and 10:23 and 10:26 LST on May 22. On the same date between 9:00 and 9:10 LST, and 9:16 and 9:26 LST, the SET* values were found 'Comfortable and Acceptable' outside of the Classroom B. Though outdoor SET* values changed more frequently in response to weather parameters, the overall comfort index trend of Classroom A was found closer to the standard comfort zone. Classroom A was located near a lake. The high thermal capacity of the lake and evaporation process reduced the air temperature and thereby dropped the SET* values down at the surrounding space of Classroom A.
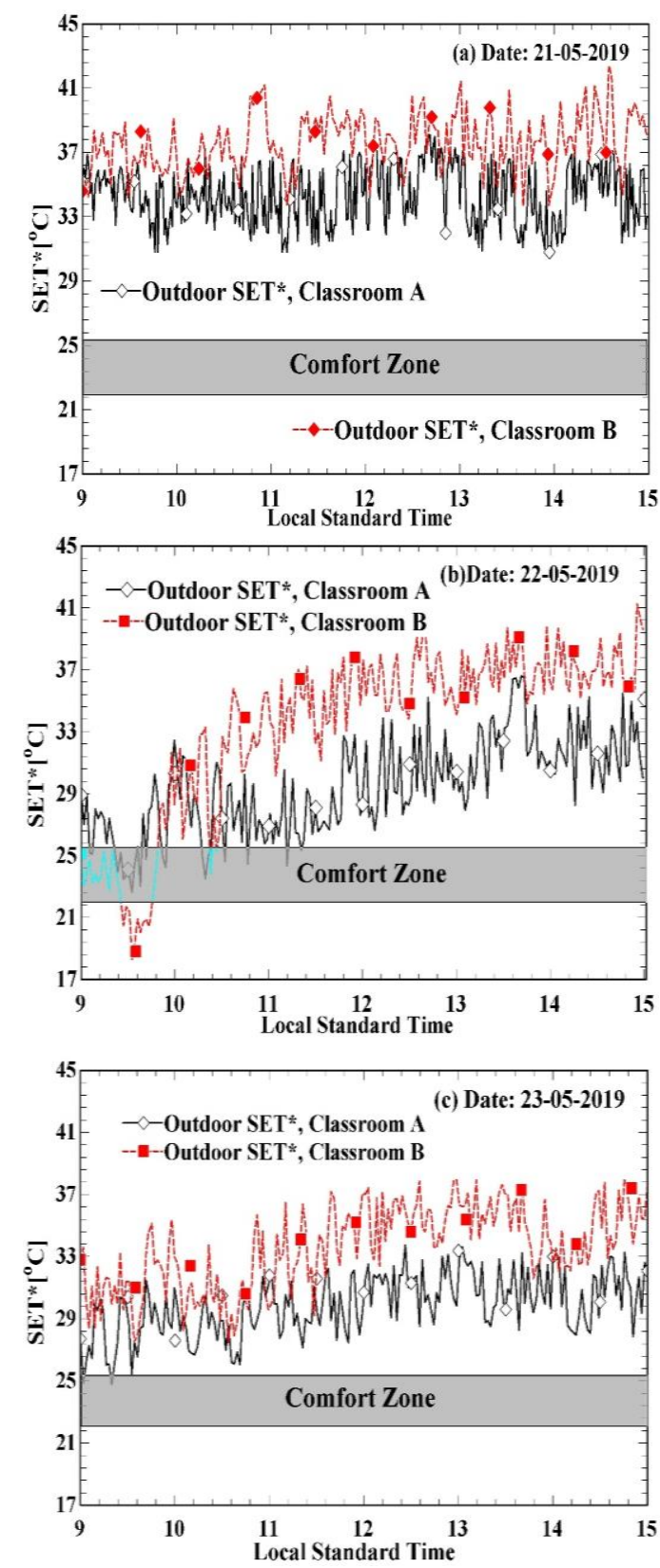

Fig. 9. Outdoor SET* trend in different dates.

Previously, several studies have been conducted to examine the effects of water bodies on the air temperature of their surrounding urban area. In Guangzhou, China, Chen, Zhao, Li and Yin [22] found a mean air temperature reduction of $1.3^{\circ} \mathrm{C}$ around a small lake. Another study by Jusuf, Wong and Syafii [9] in Singapore detected up to $1.8^{\circ} \mathrm{C}$ cooler air temperatures near the water features as compared to surrounding built areas. Guo-yu et al. [10] stated that a water body with a surface area of $16 \mathrm{~m}^{2}$ can cool by $1^{\circ} \mathrm{C}$ up to $2826 \mathrm{~m}^{3}$ of surrounding space. Syafii et al., [11] observed on average, $1.6{ }^{\circ} \mathrm{C}$ cooler pedestrian environment around the pond area. The experiment of Albdour and Baranyai [13] found the air temperature $0.6-1.5 \mathrm{~K}$ lower near the water element than the surrounding built-up area. All these studies tried to evaluate the comfort condition considering merely the air temperature as a key element of urban environment. However, thermal comfort depends both on environmental and human factors simultaneously rather than air temperature only. The present study examines the cooling effect of water body in terms of air temperature variation as well as the comfort condition by determining SET*. Since, the environmental parameters and human factors are incorporated combinedly in this comfort index, SET* can illustrates the comfort condition in more representative way. The current study reveals that lake can contribute in the reduction of outdoor air temperature up to $3.9^{\circ} \mathrm{C}$ on average compared to the non-lakeside space. Concurrently, the mean SET* values near the lake is $3.6^{\circ} \mathrm{C}$ lower than the non-lakeside space.

\section{CONCLUSION}

This study assessed indoor and outdoor thermal environment and comfort around the lakeside and non-lakeside university spaces employing the SET* model. The outdoor thermal comfort condition of Lakeside Classroom was found much closer to the standard comfort zone than Non lakeside Classroom. The lake acted as a heat sink and reduced the air temperature down on its surrounding area up to $3.9^{\circ} \mathrm{C}$ on an average. Such lower air temperature coupled with mentionable air velocity $\left(0.6 \mathrm{~ms}^{-1}\right)$ resulted in SET* values closer to the standard comfort zone. Though the outdoor weather parameters fluctuated more and affected the comfort index, on average, the $\mathrm{SET}^{*}$ values near lakeside space were found $3.6^{\circ} \mathrm{C}$ lower than non-lakeside space. However, the thermal comfort condition inside the lakeside classroom was different to some extent. The calculated SET* values inside the lakeside classroom were slightly higher $\left(0.4^{\circ} \mathrm{C}\right)$ than its non-lake side classroom counterpart. Being located on the $2^{\text {nd }}$ floor of a three storied building, the lakeside classroom was exposed to more heat gain. Furthermore, smaller window size $\left(9.1 \mathrm{~m}^{2}\right)$ and lower Window Wall Ratio (7.6\%) limited the air circulation in that classroom. The non-lakeside classroom, in contrast, is located on $2^{\text {nd }}$ floor of a four storied building with a larger Window Wall Ratio of $15.3 \%$. Hence, this classroom is less exposed to the direct solar heat gain and larger opening area for air circulation, which yielded the SET* values a little lower.

These findings indicate that indoor space needs special design considerations to utilize the cooling effect of the surrounding water body to a greater extent. Lake's windward position of the window and enlarged window area will augment the air circulation. In this particular case of the lakeside classroom, windows were placed in the right position, but air circulation was limited by the smaller window size. So, the window size needs to be enlarged on the 
east façade. There was a door and no window on the west facing wall. Some pivot type windows can be installed on the upper portion of the west facing wall. Such arrangement might increase air circulation and thereby enhance the comfort condition. In addition, mitigation of heat gain from solar radiation needs to be addressed properly, especially for the top floor of a building. 'Cool Roof' by painting the roof surface with white color and 'Green Roof' in the form of rooftop gardening is being used effectively to treat the top floor of buildings. However, the rooftop gardening is very useful in reducing the heat gain of the top floor, coupled with additional benefits like providing habitat, improving air quality, mitigating stormwater runoff, and reducing noise. To prevent the dampness of the roof, a proper drainage system should be installed and maintained.

\section{CONFLICT OF INTEREST}

The authors declare no conflict of interest.

\section{AUTHOR CONTRIBUTIONS}

F. Reza conducted the research and wrote paper; S. Kojima and W. Ando contributed to the data analysis. All authors had approved the final version.

\section{ACKNOWLEDGMENT}

Authors thank the Government of Japan, the Saga University (Japan) and Jahangirnagar University (Bangladesh) for their colossal supports during the research.

\section{REFERENCES}

[1] United Nations Human Settlement Programme (UN-Habitat), Urban Planning for City Leaders, 2nd ed. Nairobi, Kenya, 2013, ch. 1.

[2] E. S. Puliafito, R. F. Bochaca, G. D. Allende, and R. Fernandez, "Green areas and microscale thermal comfort in arid environments: A case study in Mendoza, Argentina," Atmospheric and Climate Sciences, vol. 3, pp. 372-384, 2013

[3] World Bank, Cities and Climate Change: An Urgent Agenda, vol. 10, 2010.

[4] M. Taleghani, "Dwelling on courtyards - Exploring the energy efficiency and comfort potential of courtyards for dwellings in the Netherlands," Ph.D. dissertation, Dept. Department of Architectural Engineering and Technology, Delft University of Technology, 2014.

[5] W. Triyuly, S. Triyadi, and S. Wonorahardjo, "Synergising the thermal behaviour of water bodies within thermal environment of wetland settlements," International Journal of Energy and Environmental Engineering, vol. 12, pp. 55-68, 2020.

[6] D. Wu, Y. Wang, C. Fan, and B. Xia, "Thermal environment effects and interactions of reservoirs and forests as urban blue-green infrastructures," Ecological Indicators, vol. 91, pp. 657-663, 2018

[7] N. I. Syafii, M. Ichinose, E. Kumakura, K. Chigusa, S. Jusuf and N. Wong, "Enhancing the potential cooling benefits of urban water bodies," Journal of Environmental Design and Planning, vol. 13, pp. 29-40, December 2017

[8] A. Shafaghat, G. Manteghi, A. Keyvanfar, H. B. Lamit, and K. Saito, "Street geometry factors influence urban microclimate in tropical coastal cities: A review," Environmental and Climate Technologies, vol. 17, pp. 61-75, 2016.

[9] S. K. Jusuf, N. H. Wong, N. I. Syafii, "Influence of water feature on temperature condition hot humid climate," iNTA-SEGA 2009: Bridging Innovation, Technology and Tradition, Bangkok, Thailand, 2009.

[10] C. Wan et al., "Effects of evapotranspiration on mitigation of urban temperature by vegetation and urban agriculture," Journal of Integrative Agriculture, vol. 12, pp. 1307-1315, 2013.

[11] N. I. Syafii, M. Ichinose, E. Kumakura, S. Jusuf, K. Chigusa, and N. Wong, "Thermal environment assessment around bodies of water in urban canyons: A scale model study," Sustainable Cities and Society, vol. 34, pp. 79-89, June 2017.
[12] H. Jin, T. Shao, and R. Zhang, "Effect of water body forms on microclimate of residential district," in Proc. 9th International Conference on Sustainability in Energy and Buildings, Energy Procedia, pp. 256-265, vol. 134, 2017.

[13] M. S. Albdour and B. Baranyai, "Water body effect on microclimate in summertime: A case study from pecs, pollack periodica," An International Journal for Engineering and Information Sciences, vol. 14, pp. 131-140, June 2019.

[14] H. Farajzadeh and A. Matzarakis, "Evaluation of thermal comfort conditions in Ourmieh Lake, Iran," Theoretical and Applied Climatology, vol. 107, pp. 451-459, 2012.

[15] T. Xi, Q. Li, A. Mochida, and Q. Meng, "Study on the outdoor thermal environment and thermal comfort around campus clusters in subtropical urban areas," Building and Environment, vol. 52, pp. 162-170, 2012.

[16] S. Barbhuiya and S. Barbhuiya, "Thermal comfort and energy consumption in a UK educational building," Building and Environment, vol. 68, pp. 1-11, 2013.

[17] A. D. James and K. Christian, "An assessment of thermal comfort in a warm and humid school building at Accra, Ghana," International Journal of Advances in Applied Science Research, vol. 3, pp. 535-547, 2012.

[18] M. A. H. Mondol, M. S. I. Kazi, M. F Rahman, and M. R. Rakib, "Microclimatic study using temperature data of Jahangirnagar University of Bangladesh," Climate Change, vol. 5, pp. 108-115, 2019.

[19] M. I. Nahid, "Risk of brood parasitism and predation in relation to human activity in Jahangirnagar University campus, Bangladesh," Ph.D. dissertation, NTNU-Trondheim, Norwegian University of Science and Technology, 2014.

[20] M. I. Nahid, S. Begum, and M. M. Feeroz, "Brood parasitic cuckoos and their hosts in Jahangirnagar University campus," Indian BIRDS., vol. 12 , no. $2 \& 3$, pp. 64-69, 2016.

[21] H. Tyler, S. Stefano, T. Federico, C. Toby, S. Kyle, P. Alberto and M. Dustin, CBE Thermal Comfort Tool, Center for the Built Environment. University of California Berkeley, 2019.

[22] X. L. Chen, H. M. Li, P. X. and Z. Y. Yin, "Remote sensing image-based analysis of the relationship between urban heat island and land use/cover changes," Remote Sensing of Environment, vol. 104, pp. 133-146, 2006.

Copyright $\odot 2021$ by the authors. This is an open access article distributed under the Creative Commons Attribution License which permits unrestricted use, distribution, and reproduction in any medium, provided the original work is properly cited (CC BY 4.0).

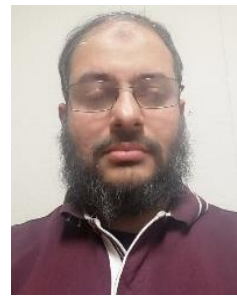

F. Reza has completed bachelor and master's degree on urban and regional planning at the Jahangirnagar University, Dhaka, Bangladesh. His research interest lies on urban environmental management and urban design in the tropics. Currently Mr. Reza is pursuing a doctoral course in the Department of Civil Engineering and Architecture at Saga University, Japan. He is a member of Bangladesh Institute of Planners (BIP).

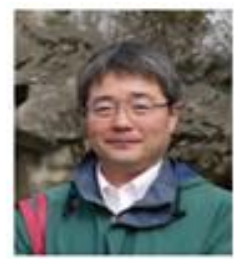

S. Kojima is a professor, Department of Civil Engineering and Architecture at Saga University, Japan. He received PhD at Kyushu University, Japan. Prof. Kojima is a member of the Architectural Institute of Japan (AIJ), the Society of Heating, Air-Conditioning and Sanitary Engineers of Japan (SHASE), and the American Society of Heating, Refrigerating an d Air-Conditioning Engineers (ASHRAE). His research interests include indoor thermal environment and heating, ventilating, and air-conditioning (hvac). he received the technology promotion award from the Society of Air-Conditioning and Sanitary Engineers of Japan in 2017 for his research on energy conservation at Saga Prefectural Hospital.

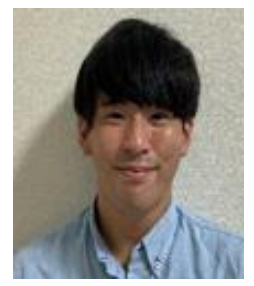

W. Ando is a master's student at the Department of Civil Engineering and Architecture at Saga University, Japan. $\mathrm{He}$ is a member of the Architectural Institute of Japan (AIJ). 